\title{
Children and teenagers working in artistic labor: Brazilian situation and international examples
}

\author{
S.R. Cavalcante ${ }^{\mathrm{a}}$ and R.A.V. Vilela ${ }^{\mathrm{b}}$ \\ a, b School of Public Health, São Paulo University, Av. Dr. Arnaldo, 715 - São Paulo/SP, Brazil - CEP 01246-904
}

\begin{abstract}
This descriptive study about children and adolescents artistic labor verifies the applicable legislation, in Brazil, regarding the participation of children and adolescents in the entertainment industry and in advertising campaigns, as well as the judicial processes about the theme known by the Brazilian Superior Court of Justice up to October, 2010. The results permit to conclude that, due to the lack of specific regulation and general rule of child labor prohibition, the restrictions that tend to protect the health and security of children and adolescents that act in the artistic niche (television, advertising, fashion, movies etc.) have been, in Brazil, at subjective criteria of the judges and, in many cases, in the hands of producers themselves. Brief considerations on how other countries regulate the theme are also presented (the USA, Portugal and Argentina).
\end{abstract}

Keywords: artistic child labor, child work, adolescent work, performing arts, entertainment industry

\section{Introduction}

Child labor is fought against in national and international campaigns that show children and adolescents in deprived neighborhoods, subjected to precocious labor. The working prohibition to the child population occur due to the losses and risks to the healthy development of these individuals. Their entrance in the working market puts them away from school, limiting their chances of building a future and can also bring irreparable consequences to their bio psychosocial health $[26,4,13,16-17,27,11,33]$. The characteristics of productive systems often become incompatible with the psychophysiological capacities of the children and adolescents [1], and the incidence of work injuries among young people is higher than among adults [34]. Natural factors of age, like immaturity, inexperience, distraction, curiosity and lack of knowledge explain the greater vulnerability of this group to occupational hazards [29].

However, the child participation in the entertainment industry and in advertising, known as artistic * child labor, is not included in such campaigns and studies, although each day it is more frequent to find

Corresponding authors: sandracavalcante@usp.br ravilela@usp.br precocious talents on TV programs, fashion shows and advertisements. Pioneer publications caused discussions about the possibility of existing an authorized child labor in the artistic segment [32, 2-3, 31, 20, 22, 28, 7].

According to the ILO (International Labor Organization) child labor is that accomplished by children and adolescents who are below the minimum age to enter the labor market, according to the legislation that is applied in this country. Therefore, the cut is flexible, varies from society to society and, in each one it changes according to the understanding of what it is to be a child or an adolescent [23]. In Brazil this cut is 16 for all kinds of jobs, except when the individual is an apprentice at the age of 14 (article $7^{\text {th }}$, XXXIII from the Federal Constitution).

This study assumes that artistic activity is essential for the formation of individuals, but this participation should take into consideration the personal characteristics of this being in development and his or her biological and psychological fragilities. The participation of children and adolescents in artistic activities with a pedagogical purpose cannot be confused with the artistic child labor, when we refer to the acting of the child artist composing a product that will be exploited commercially. Thus, even if it is a show in- 
volving children being televised, if the immediate aim is totally pedagogical, and not economical, so there is nothing related to child labor to talk about. In the case of the child artist, there is a third person benefiting from the child's performance and there is not necessarily financial payment for the artist by activity performed. Children and adolescents have the right to develop their talents, but can't be transformed into the capital source of the family, because their priorities should be play and study.

Would the different social repercussion of the activity accomplished by the child artists, that counts with the support and amazement of the society, be responsible for opening a gap to the legal prohibition of child labor in Brazil? After all, the participation of children and adolescents in artistic activities would have another framework, including legal, or everyone would be disobeying the law?

In the light of the constitutional principle of the integral protection and the ergonomic fundamental principle, that the labor must be adapted to the personal characteristics, limitations and capacities of the workers, and not the other way around [19], this paper aims to verify how (and if) the rights of the children and adolescents artists have been respected, having as a reference the prevailing legislation in our country and the questions that have already come to the last instance of the judiciary.

The accomplished bibliographic and documental survey is the initial level of a study that aims at applying ergonomics to know the artistic child labor phenomenon. In the concluded step, it was analyzed how Brazilian juridical system deals with the subject, identifying which are the applicable law to the theme and if such items have been observed by the Brazilian artistic productions, using as a parameter the judicial actions pending before the Superior Court of Justice. To understand how other countries regulate the participation of children and adolescents in show business and collect data and examples that could be applied in Brazil, the laws of Portugal, Argentina (Buenos Aires) and the United States of America were researched.

\section{Method}

The Brazilian legislation was researched in the official Federal Government website www.planalto.gov.br, with the use of the following key-words: artistic labor, child labor, artist child, labor, minor, spectacle and participation. In the Law
School's library from University of São Paulo, the writtigs containing laws interpreted and commented were studied to learn about controversial aspects of legal interpretation.

Regarding the jurisprudential research, it was chosen to know the decisions that arrived at the Superior Court of Justice. This was done by searching on the official website www.stj.jus.br/SCON, with the keywords: participation, minor and spectacle.

The foreign law was searched on the websites of the respective governments. Given the difficulty in locating publications in indexed databases Scielo, Lilacs, Web of Science, Psycinfo, Lexis Nexis e Pubmed, the Google Academics website was also used with the following keywords (in Portuguese and English): artistic child labor, entertainment industry, child actor, children in performing arts, child work.

\section{Results}

\subsection{Legislation}

\subsubsection{The minimum age for labor (Table 1)}

According to the Brazilian legislation, any job is prohibited before the age of 16 , except those applied under the condition of apprentice, at the age of 14 . Such limitation should still consider many restrictions: the sealing of subterranean activities for workers below 21; prohibition, for children and adolescents (under 18 years old), of night shifts, or any dangerous, hard, insalubrious, harmful to their physical, psychological, moral or social kind of jobs, as well as those that are located in areas which do not allow their presence at school.

The ILO convention about the minimum age for job admission (Convention $\mathrm{n} \#$ 138) [24] is an international rule that entered the Brazilian juridical order in 2002, when the minimum age of 16 was confirmed in the regulator decree. The relation of the forbidden activities before 18 and that represent the worst forms of child labor were listed in the decree that regulated another Convention (n\# 182) of ILO (decree 6481/2008). This list contains 89 kinds of jobs that are harmful to health and safety and 4 kinds that are detrimental to morality [8]. 
Table 1

The minimum age for labor

\begin{tabular}{|c|c|}
\hline Law & Devices \\
\hline Federal Constitution (1988) & $\begin{array}{l}\text { Article } 7^{\circ} \text {. They are rights of urban and rural workers, in addition to others who seek to improve their social } \\
\text { condition: } \\
\text { [...] } \\
\text { XXXIII) prohibition of night shifts, dangerous and insalubrious to workers below } 18 \text { and any job to those } \\
\text { under the age of } 16 \text {, except under the condition of apprentice, from } 14 \text { on. }\end{array}$ \\
\hline $\begin{array}{l}\text { Consolidation of Working } \\
\text { Laws }\end{array}$ & $\begin{array}{l}\text { Art. } 403 \text {. Any job to individuals below } 16 \text { years of age, except under the condition of apprentice, at } 14 \text {, is } \\
\text { forbidden. } \\
\text { Sole Paragraph: the child labor won't be allowed to be accomplished in locations that are harmful to ones } \\
\text { formation or to their physical, psychological, moral and social development or at times and locations that } \\
\text { will not allow their presence at school. } \\
\text { Art. } 404 \text {. For those under } 18 \text {, night shifts are forbidden, considering whatever it is done from } 10 \mathrm{pm} \text { to } 5 \mathrm{am} \text {. }\end{array}$ \\
\hline $\begin{array}{l}\text { Statute of the Child and } \\
\text { Adolescent (ECA) }\end{array}$ & $\begin{array}{l}\text { Art. } 60 . \text { Any job for those under } 14 \text { years of age are forbidden, except when the individual works under the } \\
\text { condition of apprentice. } \\
\text { [... } \\
\text { Art } 67 \text {. For those employed adolescents, apprentices, technical school students, assisted in governmental or } \\
\text { non-governmental entities, it is forbidden: } \\
\text { I- Night shifts, accomplished between } 10 \mathrm{pm} \text { of one day and } 5 \text { am of the next one; } \\
\text { II- dangerous, insalubrious or hard work; } \\
\text { III- jobs accomplished in harmful locations related to their formation and physical, } \\
\text { mental, moral and social development; } \\
\text { IV- held at times and places that do not allow school attendance. }\end{array}$ \\
\hline $\begin{array}{l}\text { Convention } \mathrm{n}^{\circ} 138 \text { of the } \\
\text { International Labor Organi- } \\
\text { zation - ILO }\end{array}$ & $\begin{array}{l}\text { Article 1. Every Estate-Member, in which takes effect in this constitution, compromises themselves to follow } \\
\text { a national policy that assures the effective abolition of child labor and exalts, progressively, the minimum } \\
\text { age of job admission or any job adequate to the absolute physical and mental development of the youths. } \\
\text { Article } 2.1 \text {. Every Estate-Member that validates this convention will specify, in attached declaration to their } \\
\text { validation, a minimum age for job admission or any other job in its territory and in means of transportation } \\
\text { registered in their territory; exempted the rules in the articles } 4 \text { to } 8 \text { of this convention, no individual who is } \\
\text { under this age will be admitted to a job or any occupation. }\end{array}$ \\
\hline $\begin{array}{l}\text { Decree } 4.134 / 2002- \\
\text { proclaim the Convention } 138 \\
\text { of ILO }\end{array}$ & $\begin{array}{l}\text { Art.1. The convention } 138 \text { of the international ILO about minimum age of job admission and the recommen- } \\
\text { dation } 146 \text {, only for the copy to the present decree, will be executed and accomplished so entirely as it con- } \\
\text { tains. } \\
\text { Art. } 2 \text {. To effects of article } 2 \text {, item } 1 \text {, of the convention, it is established that the minimum age for job admis- } \\
\text { sion or any occupation is } 16 \text {. }\end{array}$ \\
\hline
\end{tabular}

\subsubsection{The principle of integral protection}

The Brazilian legislator recognized, in the Federal Constitution and in the Statute of the Child and Adolescent (ECA), the vulnerability of this community and its peculiar condition of the developing person who needs absolute priority. The duty to protect these beings in formation with priority it is not only the family's and the State's, but all society's (article 227 of the federal constitution and article 4 of the Statute of Child and Adolescent).

\footnotetext{
${ }^{1}$ Article 60 of the ECA was not updated after amendment of article 7, XXXIII of the Constitution which established the minimum age to work in 16 years (Constituctional Amendment 20/2004). Thus, this article follows, so far, in disagreement with the constitution and can not be applied.
} 


\subsubsection{The artistic child labor (Table 2)}

The special laws that regulate the profession of artist and correlated professions do not do any exception about the participation of children and adolescents in these activities (Law 6533/1978 and Decree $82385 / 1978)$. Due to the lack of regulations that are clear and specific for the phenomenon of artistic child labor, the national and international rules that are applicable in the country regarding the theme need to be interpreted.

ECA does not make any reference to the arts activity when it comes to adolescent labor. But when it delimitates the competence of the Children and Adolescents jurists, includes the emission of permits to authorize the participation of children and adolescents in public performances, rehearsals and fashion shows. The same article imposes to the jurists that before authorizing, case by case, this participation, verifies the adequacy of the environment and the nature of the show to the participation of the child (art. 149, paragraph 1). It is not clear, though, if this artistic participation would only be in a pedagogical context (schools, clubs, churches) or if that would include the child's acting in the artistic economic segment, ie. in the entertainment and advertising industry.

The CLT (Consolidation of Labor Laws), on the other hand, establishes that the court order may authorize, for those who are above 14 (art.402), the work performed service in theaters, movies, cabarets and analog establishments, as well as in circus companies and others alike (art. 405, paragraph 3), since the representation has an educative context or the play is not harmful to the child's moral formation. Another predicted situation in the same article of the labor law is if the jurist verifies that the artistic ac- tivity won't bring any harm to the moral formation of the adolescent and that this occupation is essential to the maintenance of the adolescent himself or his family.

In turn, the ILO Convention 138 expressly authorizes some situations in which the child and the adolescent can act in the artistic job, even though they are under the minimum age (art. 8). Besides the specific judiciary authorization for that specific participation, this rule imposes that some restrictions are made related to working conditions and duration of activity [24]. The necessary restrictions and needful verifications to guarantee the health and security of the child or the adolescent in the artistic activity are not, however, specified neither in this nor any other rule applicable in this country.

However, the prohibitions on the list of the worst forms of child labor, that must be considered for effects in the articles 405 , I, from the CLT, meaning, sites and services that are forbidden to those workers who are under 18 (decree 88/2009), must be applied in the accomplished activities in the artistic segment. In this way, outdoor shooting without adequate protection to solar radiation, rain or cold weather, as well as exposing the child artists to psychological or physical stress, are already forbidden for those under 18 years [8].

Thus, the joint interpretation of the national and international laws applicable to the children and adolescents participation in the show business seems to enable the authorization possible, case by case, of such activities in Brazil, if there is a judiciary permit (court order) containing restrictions to protect the risks of the activity $[28,20,5,21]$. However, such opinion faces resistance from important jurists that sustain the current situation of the Brazilian legislation that does not allow child labor before $16[22,13$, $15]$.

Table 2: Legal appliance applicable to child artistic labor

\begin{tabular}{|c|c|}
\hline Law & Devices \\
\hline $\begin{array}{l}\text { Children and Ado- } \\
\text { lescents Articles of } \\
\text { Incorporation } \\
\text { (ECA) }\end{array}$ & $\begin{array}{l}\text { Art. 149. Compete to the disciplinary judiciary authority, through decree, or authorize, by a permit: } \\
\text { I - the entrance and the permanency of child or adolescent, unaccompanied by the parents or responsible guardian, } \\
\text { in: } \\
\text { a) stadiums, gymnasiums and sports field; } \\
\text { b) balls or dancing contests; } \\
\text { c) nightclubs and alike; } \\
\text { d) houses that commercially explores electronic fun; } \\
\text { e) Cinematographic studios, theaters, radio and TV; } \\
\text { II - the participation of the child and adolescent in: } \\
\text { a) Public shows and its rehearsals; } \\
\text { b) Beauty Contests. }\end{array}$ \\
\hline & $\S 1$ For the purposes of this article, the judiciary authority will consider, among other factors: \\
\hline
\end{tabular}




\begin{tabular}{|c|c|}
\hline & $\begin{array}{l}\text { a) the principles of this law; } \\
\text { b) local peculiarities; } \\
\text { c) the existence of adequate installations; } \\
\text { d) the kind of routinely frequency in the local; } \\
\text { e) the environment adequacy to any eventual participation or frequency of children or adolescents; } \\
\text { f) the nature of the show. } \\
\text { § } 2 \text { The measures adopted in conformity with this article must be based, case by case, prohibited the determinations } \\
\text { of general character. }\end{array}$ \\
\hline $\begin{array}{l}\text { Consolidations of } \\
\text { the working Laws } \\
\text { (CLT) }\end{array}$ & $\begin{array}{l}\text { Art. } 402 \text {. It is considered a minor, for the effects of this consolidation, the worker from } 14 \text { to } 18 \text { years old. } \\
\text { [...] } \\
\text { Art. } 405 \text {. It won't be allowed the job to a minor: } \\
\text { I - in local or dangerous and insalubrious activities, contents of the picture approved for this ending by the general } \\
\text { director of the Security and Hygiene department of labor; } \\
\text { II - in locations or services that harm his or her morality; } \\
\text { \$1. Revoked by Law } 10097 / 2000 \\
\text { \$2. The labor executed on the streets, squares and other public places will depend on the previous authorization } \\
\text { from the Minors Judge, to whom falls verify if the occupation is necessary for their own subsistence or of their par- } \\
\text { ents, grandparents or siblings and that occupation con not result harmful to their moral formation; } \\
\text { \$3 It is considered harmful to the morality of the minor if the work: } \\
\text { a) accomplished, in any ways, in magazine theaters, movies, nightclubs, casinos, cabarets, balls and analog } \\
\quad \text { spots; } \\
\text { b) in circus companies, working as an acrobat, juggler, gymnast or others alike; } \\
\text { [...] } \\
\text { Art. } 406 \text {. The Minors Judge may authorize the minor in the labor that refers letters a and b from paragraph } 3 \text { of art } \\
\text { I - since the representation has educative ending or the play in which the minor participates is not harmful to his } \\
\text { moral formation; } \\
\text { II - since it is verified that the minor occupation is needful to own subsistence or of their parents, grandparents or } \\
\text { siblings and does not bring any harm related to their formation. }\end{array}$ \\
\hline $\begin{array}{c}\text { Convention } \\
\mathrm{n}^{\circ} 138 \text { of } \\
\text { International } \\
\text { Labor Organization } \\
\text { (ILO) }\end{array}$ & $\begin{array}{c}\text { Article } 2 \\
\text { 1. Every estate-member that ratifies this convention will specify, in attached declaration to its ratification, a } \\
\text { minimum age for admission to employment or work in his territory and in means of transportation regis- } \\
\text { tered in their territory; except the rules in the articles } 4 \text { to } 8 \text { of this convention, no younger person than this } \\
\text { age will be admitted to employment or work in any occupation } \\
{[\ldots]} \\
\text { Article } 8 \\
1 . \\
\text { The competent authority, after consultation with organizations of employers and workers concerned, if } \\
\text { there is any, can, by licences approved in individual cases, permit exceptions to the prohibition of jobs or } \\
\text { work disposed in the article } 2 \text { of this convention, for purposes such participation in artistic representations. } \\
\text { 2. Permissions of this nature will limit the number of hours of work or employment duration and will estab- } \\
\text { lish the conditions in which it is allowed. }\end{array}$ \\
\hline
\end{tabular}

\subsection{Jurisprudence}

Online research accomplished in the STJ website (Superior Tribunal of Justice), in October, 2010, with the keys: "show", "participation" and "minor", resulted in 27 resources, being 2 about other subjects and 25 about the participation in TV programs (soapoperas and others); 2 out of these 25 came from the Tribunal of Justice of Sao Paulo and 23 from Rio de Janeiro. All of them are lawsuits sued by state prosecutor against television station that did not obey the article 149, II from ECA (Statute of Child and Adolescent), ie. no court order or judicial permits, improperly justified with the presence of the responsible legal tutor of the child or the adolescent in the place where the it artistic activity was held. All 23 actions resulted in the conviction of the TV station, with imposition of fine according to the article 258 from ECA.

\subsection{International examples}

According to a report from the National Institute for Occupational Safety and Health (NIOSH), in the USA labor is a common part of the lives of many children and most adolescents, unlike many developed nations. Although these jobs are regulated at federal level, each state also has their own child labor standards, which vary widely. This happens because the Occupational Safety and Health Act (1970), with regulates workplace health and safety protections for 
workers in the United States, doesn't make special provisions for the health and safety needs of working children and adolescents [12, 33].

In California state, the Child Artist Law (Coogan Law, created after the fight of the child artist that interpreted "The Boy", a Charles Chaplin movie, honored with his name in the law) determines that at least $50 \%$ of the value that is received by child artistkeeps deposited in a savings account that will only be withdrawn by the child when he or she is 18 years old [20]. On the other hand, there are north-American estates that allow 50 hours or more per week of labor for a child under 18 during school year [12].

Portugal has, in turn, an actual legislation with rules of protection to the participation of individuals under 16 in shows (Law 105/2009) [25]. This law restricts the number of working hours according to the age of the child artist: the maximum of one hour a week for kids under 1; three hours a week for kids from 1 to 3; two hours a day and four hours a week for kids from 3 to 7 ; three hours a day and nine hours a week for kids from 7 to 12 ; and four hours a day and 12 hours a week for kids from 12 to 16 . The article 2 of the referred law says that the minor can participate in shows or any other activity which has a cultural, artistic or advertising nature, designated as an actor, singer, dancer, figurant, musician, model or mannequin, since it does not constitute any risk for the safety or health of the minor [25].

According to a document of Portuguese PETI (Programme for the Eradication of Child Labor) [31], the participation of children and adolescents in shows, fashion and advertising is an inescapable fact of life, that caught the attention of many sectors of the Portuguese society and motivated the conception of legislative measures to protect young people from the negative effects of this participation. However, manifestations of the Portuguese society in the press indicate that the law has not been respected and that lack surveillance. The producers complain, because such protection entails new costs $[30,10,14]$.

Argentina has also legislated about the theme: the actual law of the province of Buenos Aires, signed in March 2008, aiming to protect child actors that work in theater, movies, radio or TV programs, regulates hiring, sets the obligation of a working day, between 6 am and $8 \mathrm{pm}$, and limits the working day to a maximum of four hours a day and twent hours weekly. The young people's employers must ask for an authorization to the provincial government for shows or shooting in their territory and night shifts must be permitted only due to some exceptional situation, only in cases when the artistic piece requires, as long as it does not affect the psychological or physical health of the child [6].

\section{Conclusion}

According to the interpretation of national and international laws that are applicable to children's participation in the entertainment industry, it is possible to authorize, case by case, this acting. This is the understanding that prevails among Brazilian jurists.

There is not, in the country laws, legal devices of protection to the psychological and biological fragilities of children when they are exposed to the risks and pressures of this participation, meaning, regulating and checking conditions for the artistic child labor occurs. Thus, it is the subjective criteria of each judge to define according to each situation, the limits that will impose to that authorization. There are, still, situations in which the judiciary authorization is not requested, since many producers of this market niche understand (wrongly, according to the studied jurisprudence) that there would be legal prediction demanding only the presence of a parent or tutor for that participation not to go against the law.

In this way, even considering the limitation of this study, restricted to the observation of cases that gave origin to judiciary processes and that were sent to the Superior Tribunal of Justice, it is possible to conclude that it has been left to agencies, TV stations, producers and directors to act treating with more or less care when dealing with this child participation. Even in times when there is judiciary authorization, if the terms are wide and restrictions aren't made in the permit itself, it will still be in the hands of the professionals of this segment to respect more or less this vulnerable being in development that participates in the artistic production.

Despite the importance of the research in this area, the conditions of the child artist labor were not yet studied properly, and the studies about the theme are very rare. But the artistic child labor phenomenon can be observed in most countries and, without having a clear clue of the risks of the exposition to this activity, or believing that there will be no harm, many parents have invested part of the childhood of these children in the "dream" of success in the show business.

The theme presents great relevance to the area of Public Health, since a job is one of the determinant spaces in the construction and destruction of health. The discussion about the limits of these participations of children is urgent and essential because they are 
beings that are still in formation, keepers of rights and fundamental guarantees that converge to the main right, which is the one to healthily develop in their biological, psychological and social spheres. It is important that boundaries are established on the topic of the participation of children in soap operas, movies, plays and other artistic events, just like it is already done in other countries, in a way that the artistic niche adapts their routines for work to the rights of the kids, and not the other way around.

Despite the difficulties that were verified for its accomplishment, the Portuguese regulation is a good example to be followed by Brazil, because it reveals to be like a level ahead in understanding the labor so it can be transformed. Besides the legislation containing explicit limitations to the participation of children and adolescents in the artistic ventures, the Portuguese government makes statistics available - the ones that characterize this segment of population, data that not even the government or Brazilian syndicates have, not even in estimative, according to the personal consultancy of the researcher with these organs.

Some few considerations point the research out:

a) About the possible bio-psychological impacts caused by the child labor, it is possible to realize the necessity of a more especial attention of the State and public politics, in a way to establish a special protection considering the individual and group limitation of these little artists in creating mechanisms of defense and self-regulation of his or her workload;

b) The state cannot guarantee that companies which explore the kind of labor act freely, being necessary a systematic vigilance with limits and clear rules definition;

c) The state cannot delegate the control of the exposition of this population to the family that, attracted by financial interest, glamour and fame tend to vulgarize the question of risks and future impacts of this exposition.

\section{References}

[1] A.A. Assunção and E.C. Dias, Trabalho precoce: possíveis efeitos sobre o desenvolvimento das crianças e adolescentes, Belo Horizonte: Devir; 1 (2), 2002, 61-76.

[2] A.L.R. Melro, Actividades de crianças e jovens no espectáculo e no desporto: a infância na indústria do entretenimento na contemporaneidade [masters degree dissertation], Portugal, Universidade do Minho, 2007.

[3] A.L.R. Melro, Actividades das crianças e jovens no espectáculo artístico e desportivo: a infância na indústria do entretenimento, in: Revista Pedagógica Unochapecó, ano 12, n24, jan-jun 2010, pp. 9-29. [onl line] Retrieved august 07,
2011

from http://apps.unochapeco.edu.br/revistas/index.php/pedagogica/ article/viewFile/603/396.

[4] A.L. Kassouf, $\mathrm{O}$ que conhecemos sobre o trabalho infantil? In: Nova Economia, 17(2), august - 2007. [ on line] Retrieved Nov 18, 2010, from http://www.scielo.br/scielo.php?script=sci_arttext\&pid=S0103 $-63512007000200005 \& \operatorname{lng}=$ en\&nrm=iso.

[5] A.M. Nascimento, Curso de direito do trabalho, 22ed, SãoPaulo, Saraiva, 2007.

[6] Argentina. Resolution MT n ${ }^{\circ}$ 44/2008. Retrieved July 15, 2010 , http://www.gob.gba.gov.ar/legislacion/legislacion/r-mt-0844.html.

[7] Brasil. Ministério Público do Trabalho, OrientaçõesProcuradoria Geral do Trabalho. [on line] Retrieved July 12, 2010, from http:/www.pgt.mpt.gov.br/atuacao/trabalhoinfantil/orientacoes.html.

[8] Brasil. Ministério do Trabalho e Emprego. Decreto $\mathrm{n}^{\mathrm{o}}$ 6481/2008. [on line] Retrieved August 01, 2011 from http://www.planalto.gov.br/ccivil_03/_ato20072010/2008/D6481.htm.

[9] Brasil. Consolidação das leis Trabalhistas. [on line] Retrieved August 01, 2011 from http://www.planalto.gov.br/ccivil_03/decreto-lei/Del5452.htm

[10]Correio da Manhã, Exploração infantil continua, Portugal, 12.06.2009. Retrieved July 15, 2010, from http://www.correiomanha.pt/noticia.aspx? contentid=C5D48D A0-9839-4B2B-8883-

FA9C86A079E4\&channelid $=00000010-0000-0000-0000-$ 000000000010

[11]D.C. Oliveira, C.P. Sá F.M. Fischer, I.S. Martins and L.R. Teixeira, Futuro e liberdade: o trabalho e a instituição escolar nas representações sociais de adolescentes, in: Estud. Psicologia, Natal, vol.6, n.2, 2001 [on line]. Retrieved May 24, 2010, from

http://www.scielo.br/scielo.php?script=sci_arttext\&pid=S1413 $-294 X 2001000200012 \& \operatorname{lng}=$ en\&nrm=iso

[12]D. Wegmann. Child labor in the US, in: Ciência \& Saúde coletiva, 8(4), 2003, pp. 1029-1037 [on line]. Retrieved Feb 15,2011 , from

http://www.scielo.br/scielo.php?script=sci arttext\&pid=S1413 $-81232003000400024 \& \operatorname{lng}=$ pt\&nrm=iso ISSN 1413-8123

[13]E.A. Santos, A naturalização do trabalho infantil, in: Revista do Tribunal Superior do Trabalho, 72(3), 2006, pp.105-122. [online] Retrieved Jan 21, 2011 from http://www.fnpeti.org.br/artigos/art_ea2.pdf.

[14]E. Monteiro, Miúdos faltam às aulas para viver a vida da TV. Retrieved December 7, 2010, from http://diario.iol.pt/noticia.html/?id=819414\&div_id=4071.

[15]E.R.S. Minharro, A criança e o adolescente no direito do trabalho, São Paulo, LTr, 2003.

[16]F.M. Fischer, D.C. Oliveira, L.R. Teixeira, M.C. Teixeira and M.A. Amaral, Efeitos do trabalho sobre a saúde de adolescentes, in: Ciência e Saúde Coletiva, 8(4), 2003, pp. 973-984.

[17]F.M. Fischer, I.S. Martins and D.C. Oliveira, Relatório final do projeto: saúde, educação e trabalho nos Municípios de Monteiro Lobato e Santo Antônio do Pinhal-SP, vol III, São Paulo, Faculdade de Saúde Pública da USP, 2000

[18]F. Soriano, En Provincia, los chicos actors no podrán trabajar más de 4 horas por dia, Newspaper Clarin of 31-03-2008. Retrieved December 7, 2010, from http://edant.clarin.com/diario/2008/03/31/sociedad/s02901.htm. 
[19]F.P.A. Lima, A Ergonomia como instrumento de segurança e melhoria das condições de trabalho, In: Anais do I Simpósio Brasileiro sobre Ergonomia e Segurança do Trabalho Florestal e Agrícola, Viçosa, UFV/Fundacentro, 2000.

[20]J.R.D. Oliva, O Trabalho Infanto-juvenil artístico e a idade mínima: sobre a necessidade de regulamentação e a competência para sua autorização, in: Revista da Associação dos Magistrados da Justiça do Trabalho da $15^{\mathrm{a}}$ Região, $\mathrm{n}^{\mathrm{0}} 3$, São Paulo, LTr, 2010, pp.120-152.

[21]L.C.A. Robortela and A.G. Peres, Trabalho artístico da criança e do adolescente: valores constitucionais e normas de proteção, in: Revista LTr, v.69, n.2, São Paulo, LTr, FEB 2005, pp. 148-17.

[22] O. Oliveira, Trabalho Infantil Artístico, Rio de Janeiro, 2007. [monograph on line], Retrieved aug 10, 2010 from http://www.fnpeti.org.br/artigos/trabalho_artistico.pdf/view

[23] OIT/ILO - International Labor Organization, Combatendo o Trabalho Infantil: guia para educadores, Brasília, 2001. [on line] Retrieved December 7, 2010, from http://white.oit.org.pe/documentos/escola1_br.pdf.

[24] OIT/ILO - International Labor Organization, Convencion 138. Retrieved December 7, 2010, from http://www.oitbrasil.org.br/info/download/conv_138.pdf.

[25] Portugal. CNPCJR- Comissão Nacional de Proteção das Crianças e Jovens em Risco. Lei 105/2009 de 14 de setembro. Retrieved July 15, 2010, from http://www.cnpcjr.pt/preview_documentos.asp?r=2622\&m=P DF

[26]R.A.G. Vilela and M.A.L. Ferreira, Nem tudo brilha na produção de jóias de Limeira/ SP, in: Produção, 18 (1), 2008, pp. 183-194 [on line] Retrieved Jan 21, 2011 from http://www.scielo.br/scielo.php?script $=$ sci arttext\&pid=S0103 $-65132008000100014 \& \operatorname{lng}=$ en\&nrm $=$ iso

[27]R. Galli, The economic impact of child labour, in: ILO Decent Work Research Programme, Genetra, 2001. [paper on line] $\begin{array}{llll}\text { Retrieved jan } 10, & \text { from }\end{array}$ http://www.ilo.org/public/english/bureau/inst/publications/dis cussion/dp12801.pdf.

[28]R.D. Marques, Trabalho Infantil Artístico: possibilidades e limites, 2010. [on line] Retrieved july 15, 2010, from http://www.pgt.mpt.gov.br/images/arquivos/artigoTrabalho Infantil Artistico.pdf.

[29]R.N. Franklin, E.C.M.M. Pinto, J.T. Lucas, M. Linné, R. Peixoto, M.T.N. Sauer, C.H. Silva, P.J.H. Nader, Trabalho precoce e riscos à saúde, in: Rev Adolescência Latinoamericana, 1414-7130/2, 2001, pp. 80-89

[30]RTP- Rádio e Televisão de Portugal, Meia centena de jovens condenam participação de crianças em novelas e séries juvenis, 22.07.2007. [on line] Retrieved July 15, 2010, from http://tv1.rtp.pt/noticias/?t=Meia-centena-dejovens-condenamparticipacao-de-criancas-em-novelas-e-seriesjuvenis.rtp\&article $=47931$ \&visual $=3$ \&layout $=10 \& \mathrm{tm}=8$.

[31]S. Bahia, I. Pereira e P. Monteiro, Participação em espectáculos, moda e publicidade: Fama enganadora, in: J. Cadete (Org.), PETI: 10 anos de combate à exploração do trabalho infantil, Lisboa, 2008, MTSS / PETI - Fundo Social Europeu, pp. 207-242. [on line], Retrieved August 07, 2011, from http://repositorio.ul.pt/handle/10451/2708.

[32] S.R. Cavalcante, Trabalho Infantil Artístico: do deslumbramento à ilegalidade, LTr, São Paulo, 2011.

[33]USA. NIOSH - National Institute for Occupational Safety and Health, Special hazards review - Child Labor Research Needs - Recommendations from the NIOSH child labor work team, 1997. Retrieved July 15, 2010 from http://www.cdc.gov/niosh/docs/97-143/.
[34] V. S. Santana, S.P. Cooper, R.E. Roberts, J.B. Araújo Filho, Adolescent students who work: gender differences in school performances and self-perceived health. Int J Occup Environ Health, 11, 2005, 294-301. 